International Journal of Advanced Chemistry, $9(1)(2021) 49-54$
International Journal of Advanced Chemistry
SPC
Website: www.sciencepubco.com/index.php/IJET
Research paper

\title{
Synthesis, characterization and antimicrobial evaluation of silver nanoparticles embedded alkyd resin derived from pine seed oil
}

\author{
A Magaji ${ }^{1}$ *, H Musa ${ }^{2}$, F A Sheshe ${ }^{3}$, S I Alhassan ${ }^{3}$ \\ ${ }^{1}$ Department of Chemistry, Sule Lamido University Kafin-Hausa, Jigawa State, Nigeria \\ ${ }^{2}$ Department of Pure and Industrial Chemistry, Bayero University Kano, Kano State, Nigeria \\ ${ }^{3}$ Department of Chemistry, Kano University of Science and Technology, Wudil Kano, Nigeria \\ *Corresponding author E-mail: fasheshe@gmail.com
}

\begin{abstract}
Silver nanoparticles were synthesized by reducing $0.1 \mathrm{mmol}$ silver Nitrate salt with $5 \mathrm{ml}$ of neem leaf extract, in an environmental friendly process. The nanoparticles were tested to have strong zones of inhibition on the antibacterial and antifungal isolates; E. Coli, staphylococcus aureus, Aspergillus fumigatus, and mucor species used. UV-visible spectrophotometric analysis was carried out on both the silver nitrate salt and silver nanoparticles, which show bathochromic shift from $221 \mathrm{~nm}$ (AgNO3) to 440nm (AgNPs). Pine seed oil was condensed to alkyd resin via two step reactions; alcoholysis and esterification reactions respectively, and was characterized by FTIR, acid value and viscometric measurement. Antimicrobial evaluation was carried out on the pine seed oil with its alkyd resin. Pine alkyd resin was used in the formulation of paints with percentage Pigment Volume Concentrations (\%PVC) 4 and 5\% respectively, and is classified as automotive clearcoat. Chemical resistance, scratch resistance, light fastness, and drying schedule tests were conducted on the paints and are found to exhibit good properties which are similar to commercial paints. Antimicrobial evaluation of the paints incorporated with silver nanoparticles revealed more inhibition zones than those without silver nanoparticles.
\end{abstract}

Keywords: AgNO3; AgNPs; \%PVC; Paints; PSO; PSOR.

\section{Introduction}

Alkyd resin is an essential material used in paint formulation and other surface coatings as a binder. However, because of its nonavailability, alkyd resin is largely being imported for industrial consumptions. Vegetable oil is an important raw material for alkyd resin production. They are polyester products formed from the polymeric condensation of polyhydric alcohol, polybasic acid and monobasic fatty acids.

Formation of organic coatings may be simple or complex in composition of variety of materials, each having a specific function. Formulation has three major components; Pigments, binder/ vehicle and additives. The pigment provides colorant and other functions. The binder sticks together the pigments with substrate and to each other. And additives are substances which modify or improve the properties of a coating.

The type or class of alkyd resin to be produced is another main consideration for the choice of modifying oil. Alkyd resins have been classified based on the kind and amount of oil used for its production (Kirk \& Othmer, 1966), it can be regarded as drying and nondrying based on the oil length, i.e. short oil 35\%, medium oil 40-55\%, long oil 56-70\% and very long oil alkyd having an oil content of more than $70 \%$. Most drying alkyds are modified using semi-drying or drying oils. High degree of unsaturation enables thin film of alkyds to polymerize in the presence of oxygen at room temperature to give a solid film. However, non-drying alkyds based on non-drying oil are used as blending agents for other resins (Odetoye et al, 2012).

\section{Materials and methods}

\subsection{Materials}

The reagents used were prepared using standard analytical method of preparation. Pine seed oil was purchased from National Board for Technology Incubation Centre kano, Nigeria, Neem leaf (Azaradichta indica) was obtained from the abundant neem trees in Bayero University Kano, Nigeria. Some of the materials used are; UV-Visible spectrophotometer, FTIR machine, Autoclave, agar plates.

\subsection{Methods}

Copyright $(\odot$ A Magaji et al. This is an open access article distributed under the Creative Commons Attribution License, which permits unrestricted use, distribution, and reproduction in any medium, provided the original work is properly cited. 


\subsubsection{Green synthesis of the silver nanoparticle}

Neem leaves obtained were washed thoroughly with tap water followed by rinsing with distilled water and then air dried. $10 \mathrm{~g}$ of the finely cut neem leaves were weighed and heated to boil with $100 \mathrm{~mL}$ of distilled water, the extract is then filtered and cooled. $15 \mathrm{ml}$ of $1 \mathrm{mmol}$ $\mathrm{AgNO}_{3}$ was then reacted with $5 \mathrm{ml}$ of neem leaf extract, and the colour changed slowly at room temperature overnight to deep brown.

\subsubsection{Physico-chemical analysis of pine seed oil with its alkyd resin and characterization of silver nanoparticle}

The physico-chemical properties such as; acid value, refractive index, iodine value, saponification number, specific gravity, percentage free fatty acid and characterization of the silver salt, silver nanoparticle through FTIR and UV-Visible analysis and FTIR characterization of the pine seed oil sample was determined in accordance with American Oil Chemists Society method (AOCS).

\subsubsection{Synthesis of the pine alkyd resin}

Synthesis of pine alkyd resin was carried in two step reactions; alcoholysis and esterification reactions. In the alcoholysis reaction, measured amounts of the triglycerides(pine oil) were placed into $1000 \mathrm{~mL}$ of three neck round bottom flask fitted with dean and stark apparatus and heated to $120^{\circ} \mathrm{C}$ to expel the moisture content of the oil. To this a measured quantity of glycerol and calcium carbonate (catalyst) were added and continued heating for $40 \mathrm{mins}$ at a temperature of $230^{\circ} \mathrm{C}$, until a monoglyceride forms when an aliquot of the solution dissolved completely in a methanol. In the esterification reaction, the temperature of the solution was lowered to about $180^{\circ} \mathrm{C}$, and the flask is connected with $\mathrm{N}_{2}$, to this a weighed phthalic anhydride, $10 \mathrm{grams}$ of xylene were added in each synthesis to aid distilling off of water of esterification by forming an azeotrope. The solution was heated for $2 \mathrm{hrs}$ at $240-250^{\circ} \mathrm{C}$ and an aliquot was drawn at an interval of 30 mins to check for the drop in acid value, as shown from the table of formulation below.

Table 1: Compositions of Alkyd Resin of Pine Seed Oils

\begin{tabular}{ll}
\hline Raw Materials & Alkyd Resin of Pine Seed Oil \\
\hline Oil $(\mathrm{g})$ & 85.84 \\
Pthalic anhydride(g) & 43.42 \\
Glycerol(g) & 18 \\
Oil length & 58.29 \\
\hline
\end{tabular}

\subsubsection{Antibacterial and antifungal evaluation}

The activity was carried out by employing paper disc diffusion method, in which the agar plates were incubated with test organisms (E. Coli, staphylococcus aureus, Aspergillus fumigatus, and mucor species) by spreading uniformly. One disc from each sample was placed in the petri-dishes with sterile forceps. The dishes were incubated for 24 hours at $37^{\circ} \mathrm{C}$. After 24 hours, the antibacterial activity of test compound was found by measuring the zone of inhibition.

\subsubsection{Alkyd paints formulation and performance evaluations}

The paint was formulated based on pigment volume concentrations (PVC) which guides the manufacture of paint in desired properties. $\mathrm{PVC}$ is the concentration by volume of the pigment expressed as a percentage of the total non-volatile volume of the paints.

$\% \mathrm{PVC}=\frac{\mathrm{Vp}}{\mathrm{Vp}+\mathrm{Vb}} \times 100 \%$

Where;

$\mathrm{V}_{\mathrm{p}}=$ Volume of pigment dispersion

$\mathrm{V}_{\mathrm{b}}=$ Volume of binder.

Paint is applied on a glass slides to taste the drying through period of the paints. The dried paints each on a glass slide are immersed in to water, hydrochloric acid, and sodium hydroxide to test their chemical resistance. Scratch resistance, flexibility and light fastness were also tested

\section{Results}

Table 2: UV-Visible Spectrophotometry of the $\mathrm{Agno}_{3}$ and Agnp

\begin{tabular}{ll}
\hline Materials & $\lambda \mathrm{max}(\mathrm{nm})$ \\
\hline Aqueous solution of Silver Nitrate salt & 221 \\
Silver nanoparticle colloidal solution & 440 \\
\hline
\end{tabular}

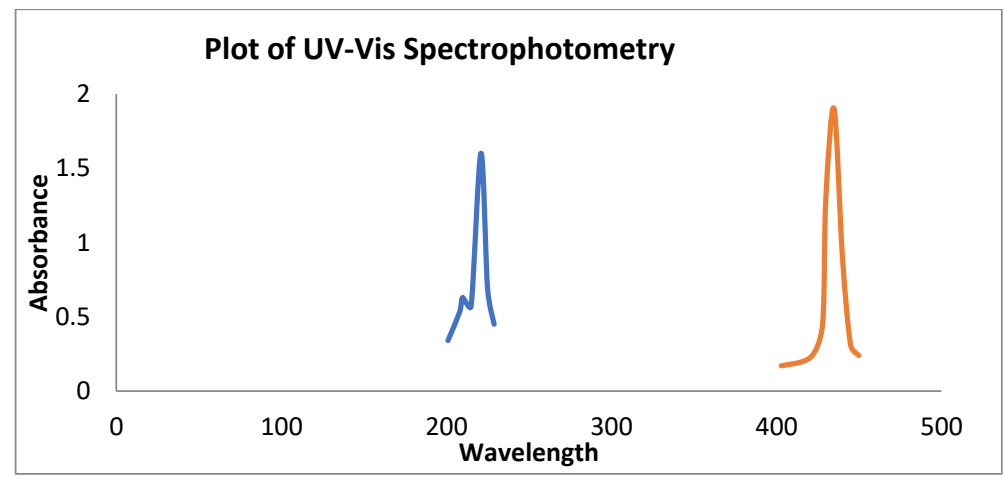

Fig. 1: UV-Visible Spectroscopy of $\mathrm{AgNO}_{3}$ and $\mathrm{AgNP}$. 
Silver nanoparticles were synthesized by weighing $10 \mathrm{~g}$ of the finely cut neem leaves and heated to boil with $100 \mathrm{ml}$ of distilled water.

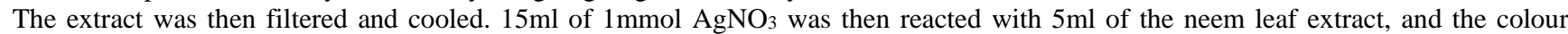
changed slowly at room temperature overnight to deep brown. The AgNP was then characterized using UV-Vis spectrophotometer. Table 2 and Figure 1 showed a bathochromic shift from $221 \mathrm{~nm}\left(\mathrm{AgNO}_{3}\right)$ to $440 \mathrm{~nm}(\mathrm{AgNP})$. Shifting of absorption band from UV region to visible region confirmed the formation of the nanoparticle, which typically attributed to plasmon resonance of silver nanoparticles. Silver nanoparticles were synthesized according to the method described in the previous section, the colloidal solution turned pale brown, pale yellow and pale red indicating that the silver nanoparticles were formed. The UV-Visible spectroscopy revealed the formation of silver nanoparticles by exhibiting the typical surface plasmon absorption maxima at 418-420nm (Maribel et al, 2009).

Table 3: Physico-Chemical Analysis of PSO

\begin{tabular}{ll}
\hline Properties & Pine Seed Oil \\
\hline Acid Value & 2.08 \\
Iodine Value & 118.41 \\
Saponification Number $(\mathrm{mg} / \mathrm{g})$ & 193.7 \\
Refractive Index & 1.465 \\
PFFA (\%) & 1.04 \\
Specific Gravity $\left(\mathrm{g} / \mathrm{cm}^{3}\right)$ & 0.8791 \\
Viscosity (MPa at $\left.28^{\circ} \mathrm{C}\right)$ & 15.41 \\
Moisture Content $(\%)$ & 0.22 \\
pH & 5.2 \\
\hline
\end{tabular}

The physico-chemical analysis result in Table 3 showed that, iodine values of pine seed oil was $118.41(\mathrm{cg} / \mathrm{g})$, and have been identified to possess high degree of unsaturation and therefore higher tendency to undergo oxidative rancidity (Ayo et al 2007). The saponification value of the pine seed oil was $179.8(\mathrm{mg} / \mathrm{g})$ which is the indication of the average molecular mass of fatty acid present in the oil, and is found to be slightly above the range reported by (Ogunniyi et al 2006). Acid value of pine seed oil as obtained from the result of analysis was $2.08(\mathrm{mgKOH} / \mathrm{g})$, and it's the measure of the extent to which the constituent glycerides have been decomposed by lipase action, and has shown to be the general indication of the edibility of the oil (AOCS 1996). The refractive index of the oil was found to be 1.465 , specific gravity of the oil was $0.63\left(\mathrm{~g} / \mathrm{cm}^{3}\right)$ which implies that they are less dense than water (Momodu et al 2011). Percentage free fatty acids of pine seed oil obtained was $1.04 \%$, while the viscosity of the oil at $28^{\circ} \mathrm{C}$ was found to be $15.41 \mathrm{Mpa}$, moisture content of the pine seed oil was found to be $0.22 \%$.

Table 4: FTIR Spectral Absorption of PSO and PSOR

\begin{tabular}{ll} 
& Table 4: FTIR Spectral Absorption of PSO and PSOR \\
\hline Bands $\left(\mathrm{cm}^{-1}\right)$ & FTIR Peak \\
\hline 3478 & O-H stretch due to alcohol \\
2961 & C-H stretch due to alkane \\
1449 & C-C stretch due to aromatic ring \\
1112 & C-O stretch due to ester \\
2922 & C-H stretch due to alkane \\
1723 & C=O stretch due to ester \\
1451 & C-C stretch due aromatic ring \\
1259 & C-O stretch due to ester \\
\hline
\end{tabular}

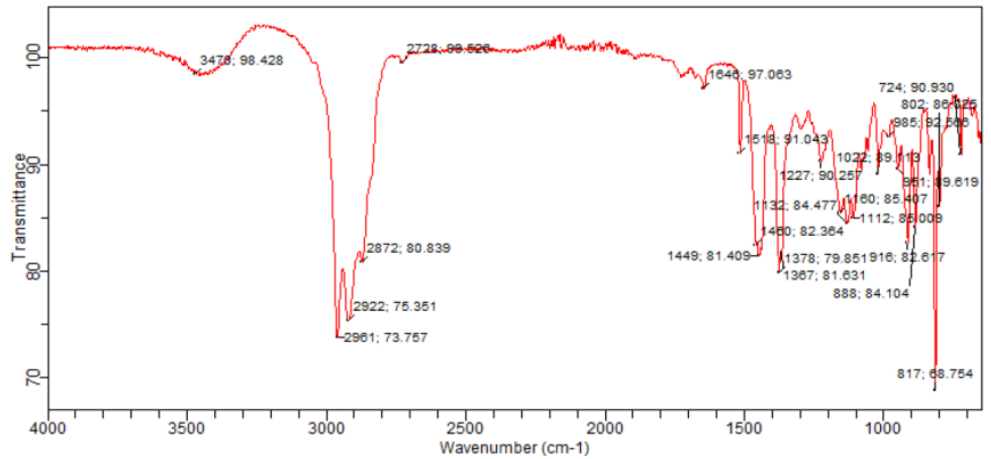

Fig. 2: FTIR Analysis of PSO.

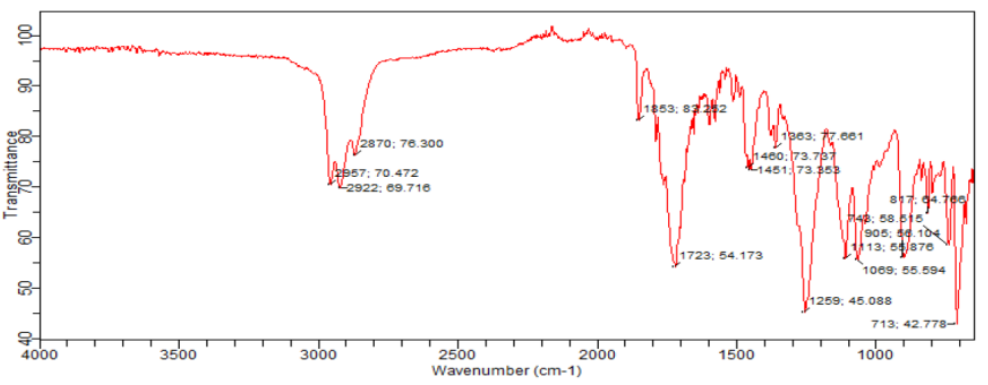

Fig. 3: FTIR Analysis of PSOR

Table 6, figures 2 and 3 shows FTIR result of pine seed oil and its respective alkyd resin with spectral absorption at band positions; $3478 \mathrm{~cm}^{-1}$, indicates $\mathrm{O}-\mathrm{H}$ stretching due to alcohol, $2961 \mathrm{~cm}^{-1}$, indicates $\mathrm{C}-\mathrm{H}$ stretching due to alkane, and $1449 \mathrm{~cm}^{-1}$, indicates C-C stretching due to aromatic ring, and $1112 \mathrm{~cm}^{-1}$, indicates $\mathrm{C}-\mathrm{O}$ stretching due to ester. Alkyd resin of pine seed oil with spectral absorption 
at band positions; $2922 \mathrm{~cm}^{-1}$, indicates $\mathrm{C}-\mathrm{H}$ stretching due to alkane, $1723 \mathrm{~cm}^{-1}$, indicates $\mathrm{C}=\mathrm{O}$ stretching due to ester, $1451 \mathrm{~cm}^{-1}$, indicates $\mathrm{C}-\mathrm{C}$ stretching due to aromatic ring, and $1259 \mathrm{~cm}^{-1}$, indicates $\mathrm{C}-\mathrm{O}$ stretching due to ester.

Table 5: Result of Acid Values (mgKOH/g) of PSOR

\begin{tabular}{ll}
\hline Neem & Time $(\min )$ \\
\hline 32.8 & 30 \\
23.0 & 60 \\
15.0 & 90 \\
9.3 & 120 \\
\hline
\end{tabular}

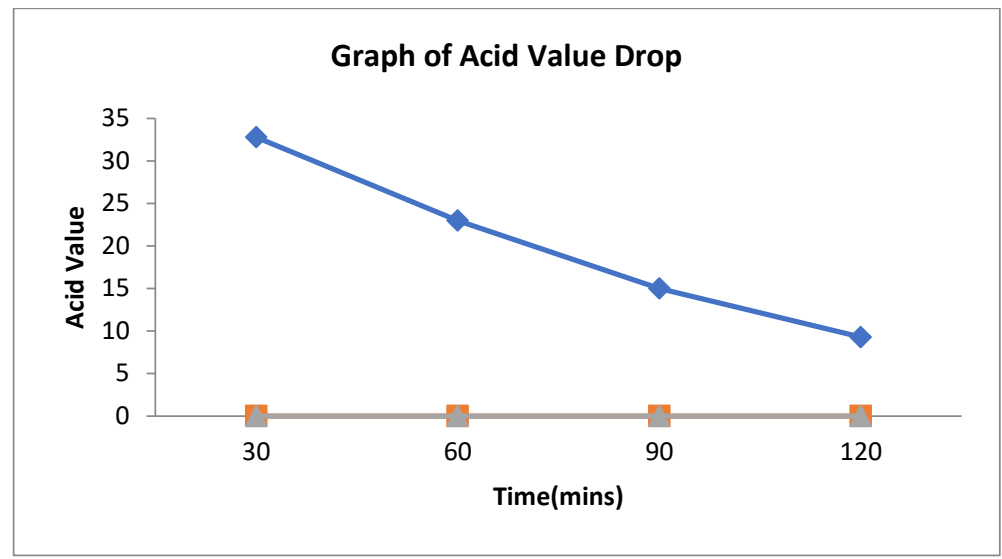

Fig. 4: Acid Value Drop of PSOR.

Table 7 and figure 4, showed acid value of pine seed oil with reaction time. It was found that the acid values decreases with increasing the reaction time, due to the reactivity of primary and secondary hydroxyl groups of glycerol with carboxyl groups of the phthalic anhydride as reported by (Oladipo et al 2013).

Table 6: Viscosity Results for PSOR at $25 \pm 0.1^{\circ} \mathrm{C}$ in $15 \mathrm{ml}$ of Acetone Using Ostwald Viscometer

\begin{tabular}{llllll}
\hline Conc. $(\mathrm{g} / \mathrm{L})$ & $\mathrm{t}_{\mathrm{o}}(\mathrm{sec})$ & $\mathrm{t}(\mathrm{sec})$ & $\eta_{\mathrm{r}}=\mathrm{t} / \mathrm{t}_{\mathrm{o}}$ & $\eta_{\mathrm{sp}}=\frac{\mathrm{t} \text {-to }}{\text { to }}$ & \\
\hline 0.125 & 126 & 128 & 1.016 & 0.016 & $\eta_{\text {sp/C }}$ \\
0.25 & 126 & 129 & 1.023 & 0.023 & 0.128 \\
0.50 & 126 & 133 & 1.056 & 0.056 & 0.092 \\
1.00 & 126 & 145 & 1.150 & 0.150 & 0.112 \\
\hline
\end{tabular}

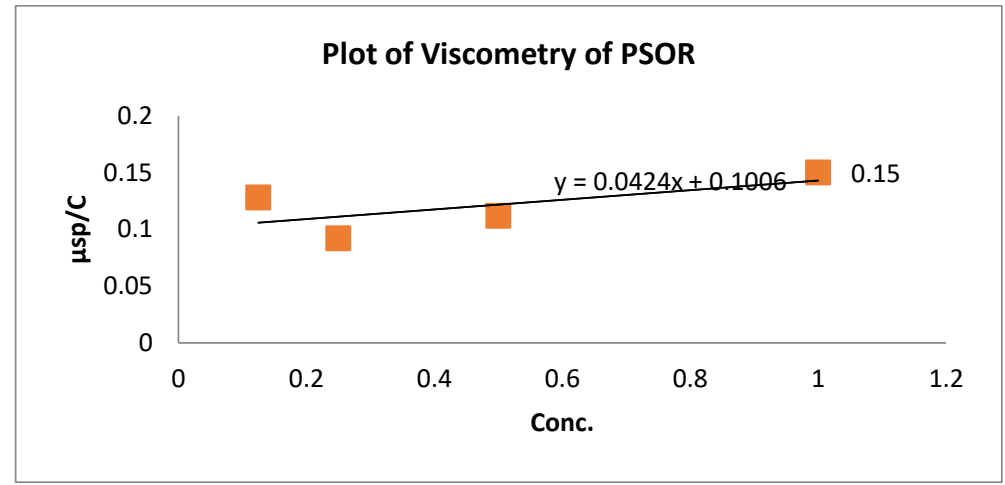

Fig. 5: Viscometric Analysis of PSOR.

Table 8 and Figure 5 showed viscometric analysis of PSOR, and was found that the time flow of the alkyd resin dissolved in acetone in the viscometer, increases with increasing the amount of the alkyd resin, while volume of the solvent was maintained. Hence, the viscosity of the resin was found to be increasing.

Table 7: Antibacterial and Antifungal Evaluation of $\mathrm{AgNO}_{3}$ and $\mathrm{AgNPs}$

\begin{tabular}{|c|c|c|c|c|c|c|c|}
\hline \multirow{2}{*}{ Test organisms } & \multicolumn{6}{|c|}{ Zone of inhibition $(\mathrm{mm}) /$ concentration $(\mu \mathrm{g} / \mathrm{ml})$} & \multirow{2}{*}{$\begin{array}{l}\text { Control (X) } \\
3 \times 10^{3}\end{array}$} \\
\hline & $1 \times 10^{3}$ & $2 \times 10^{3}$ & $3 \times 10^{3}$ & $1 \times 10^{3}$ & $2 \times 10^{3}$ & $3 \times 10^{3}$ & \\
\hline Eschricia coli & 12 & 13 & 15 & 16 & 18 & 20 & Ampicilline 21 \\
\hline staphylococcus aureus & 13 & 14 & 16 & 19 & 21 & 22 & 24 \\
\hline Aspergillus fumigatus & 13 & 15 & 16 & 20 & 23 & 26 & Ketoconazole 34 \\
\hline Mucor specie & 11 & 13 & 15 & 17 & 18 & 22 & 25 \\
\hline
\end{tabular}

Tables 7 shows the antibacterial and antifungal screening of $\mathrm{C}_{7} \mathrm{H}_{5} \mathrm{O}_{2} \mathrm{Ag}$ and AgNPs, with strong activities in silver nanoparticles than the silver salt, but all increases with increasing the concentrations of the salts and AgNPs respectively. Sondi \& Alopek, (2007) reported that the antibacterial activity of silver nanoparticles on Gram-negative bacteria was dependent on the concentration of Ag nanoparticle, and was closely associated with the formation of 'pits' in the cell wall of bacteria. Then, Ag nanoparticles accumulated in the bacterial membrane caused the permeability, resulting in cell death and they reported degradation of the membrane structure of microorganism with silver nanoparticles 
Table 8: Antimicrobial and Antifungal Activity of Alkyd Resin of PSO and PSOR

\begin{tabular}{|c|c|c|c|c|c|c|}
\hline \multirow{2}{*}{ Test organisms } & \multicolumn{6}{|c|}{ Zone of inhibition $(\mathrm{mm}) /$ Concentration $(\mu \mathrm{g} / \mathrm{ml})$ Control } \\
\hline & $1 \times 10^{3}$ & $2 \times 10^{3}$ & $3 \times 10^{3}$ & $4 \times 10^{3}$ & $5 \times 10^{3}$ & $5 \times 10^{3}$ \\
\hline Staphylococcus aureus & 6 & 6 & 6 & 6 & 6 & Ampicilline 26 \\
\hline Eschericia coli & 6 & 6 & 6 & 7 & 9 & 21 \\
\hline Aspergillus fumigatus & 6 & 6 & 6 & 7 & 10 & Ketoconazole 38 \\
\hline Mucor specie & 6 & 6 & 6 & 7 & 8 & 25 \\
\hline Staphylococcus aureus & 6 & 6 & 6 & 7 & 8 & Ampicilline 26 \\
\hline Eschericia coli & 6 & 6 & 7 & 8 & 11 & 21 \\
\hline Aspergillus fumigatus & 6 & 6 & 6 & 7 & 11 & Ketoconazole 38 \\
\hline
\end{tabular}

Tables 8 showed antibacterial and antifungal properties of pine seed oil with its respective alkyd resin. In PSO, absence of activities was observed in all the four organisms used at lower concentrations $\left(1 \times 10^{3}-3 \times 10^{3}\right)$, and very poor activities at higher concentrations $\left(4 \times 10^{3}\right.$ $\left.-5 \times 10^{3}\right)$ as compared with the control. While in the PSOR result, absence of activities was observed in all the four organisms used at lower concentrations $\left(1 \times 10^{3}-2 \times 10^{3}\right)$, a very poor and even zero activity activities was recorded at higher concentrations $\left(3 \times 10^{3}-5 \times 10^{3}\right)$ as compared with the control.

Table 9: Composition of Alkyd Resin Paints of Pine Seed Oil with their \% PVC

\begin{tabular}{llllllllll}
\hline & $\mathrm{Resin}(\mathrm{g})$ & $\mathrm{Fe}_{2} \mathrm{O}_{3}(\mathrm{~g})$ & $\mathrm{TiO}_{2}(\mathrm{~g})$ & Solvent $(\mathrm{ml})$ & $\mathrm{AgNP}(\mathrm{ml})$ & $\mathrm{Thickner}(\mathrm{g})$ & Extender $(\mathrm{g})$ & $\mathrm{Drier}(\mathrm{ml})$ & $\mathrm{PVC} \%$ \\
\hline $\mathrm{P}_{1}$ & 10 & 7 & 0 & 30 & 1 & 0.2 & 0.4 & 0 \\
$\mathrm{P}_{2}$ & 10 & 0 & 7 & 30 & 0 & 0.2 & 0.4 & 5 & 0 \\
\hline
\end{tabular}

Where;

$\mathrm{P}_{1}=$ Paint of alkyd resin of pine seed oil with nanoparticle

$\mathrm{P}_{2}=$ Paint of alkyd resin of pine seed oil without nanoparticle

Table 9 showed a composition and amounts of the components used in the formulation of alkyd paint and their respective \%PVCs. Quantities of alkyd resin of pine seed oil was maintained in each formulation, two different types of pigments were used and silver nanoparticle was used in one of the formulations, to test the influence of the additives in the properties of the paint formed. In $\mathrm{P}_{1}$ formulation, silver nanoparticle was used as an additive, and the pigment used was $\mathrm{Fe}_{2} \mathrm{O}_{3}$. While in $\mathrm{P}_{2}$ paint no nanoparticle was added, and the pigment used was $\mathrm{TiO}_{2}$. The PVC\% of paints formulated are all <5\% and are used in automotive clearcoats. (Uppal, 2006).

Table 10: Evaluation Tests of the PSOR Paint

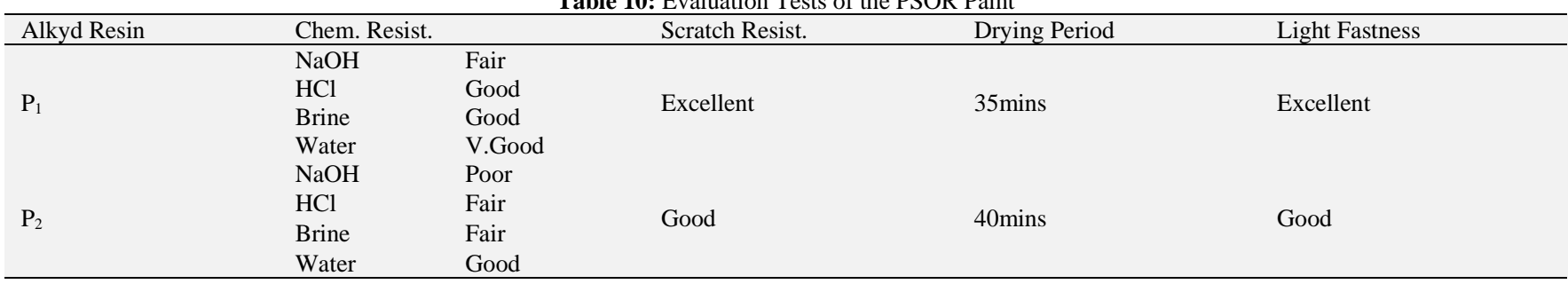

Tables 10 showed the evaluation and performance tests carried out on different alkyd paints formulated. Resistance to chemical attacks by $\mathrm{HCl}, \mathrm{H}_{2} \mathrm{O}$ and Brine on $\mathrm{P}_{1}$ alkyd paint was found to be generally good, but poor with $\mathrm{NaOH}$. While in $\mathrm{P}_{2}$ alkyd paint, fair resistance was observed with the chemical with exception of $\mathrm{NaOH}$ which is poor. This is because nanomaterials represent almost the ultimate in increasing surface area and they are chemically very active because the number of surface molecules or atoms is very large compared with the molecules or atoms in the bulk of the materials, and because of greater surface activity of nanoparticles, they can absorb more resins compare to conventional pigments and thus reduce the free space between the pigment and the resin (Mathiazhagan and Rani, 2011). Scratch resistance in $P_{1}$ and $P_{2}$ shows performances of excellent and good respectively, and this is due to higher iodine value $118.41(\mathrm{cg} / \mathrm{g})$ of pine seed oil, which have been identified to possess high degree of unsaturation and therefore higher tendency to undergo oxidative rancidity (Ayo et al, 2007). The drying schedule of the alkyd paints; $\mathrm{P}_{1}$ and $\mathrm{P}_{2}$ were found to be $35 \mathrm{mins}$ and $40 \mathrm{mins}$ respectively, this also due to the level of unsaturation. Light fastness rating of the alkyd paints $\mathrm{P}_{1}$ and $\mathrm{P}_{2}$ were; excellent and good respectively, Silver nanoparticles have application in some spectrally selective coating and enhance raman scattering (Kim et al, 2011).

Table 11: Antibacterial and Antifungal Evaluations of Alkyd Paints of PSO

\begin{tabular}{|c|c|c|c|c|c|c|c|}
\hline \multirow[t]{3}{*}{ Test Organism } & \multicolumn{6}{|c|}{ Zone of inhibition $(\mathrm{mm}) /$ Concentration $(\mu \mathrm{g} / \mathrm{ml})$ with and without AgNP } & \multirow{3}{*}{$\begin{array}{l}\text { Control } \\
3 \times 10^{3} \\
\text { Ampicilline }\end{array}$} \\
\hline & \multicolumn{3}{|c|}{ PSO } & \multicolumn{3}{|c|}{ PSOR } & \\
\hline & $1 \times 10^{3}$ & $2 \times 10^{3}$ & $3 \times 10^{3}$ & $1 \times 10^{3}$ & $2 \times 10^{3}$ & $3 \times 10^{3}$ & \\
\hline Eschericia coli & 6 & 6 & 6 & 16 & 17 & 18 & $\begin{array}{l}21 \\
\text { Ketoconazole }\end{array}$ \\
\hline Aspergillus fumigatus & 6 & 6 & 6 & 18 & 20 & 21 & 34 \\
\hline Mucor specie & 6 & 6 & 6 & 15 & 17 & 20 & 25 \\
\hline
\end{tabular}

Tables 11 expressed the Antibacterial and Antifungal evaluations of Pine alkyd resin paints, with strong inhibition zone in the organisms incorporated with various concentrations of the silver nanoparticles.

\section{Conclusion}

Synthesis of silver nanoparticles using an eco-friendly green synthetic method has been successful as confirmed by UV-visible spectrophotometry and colour transformation. The nanoparticles were incorporated into the synthesized alkyd resin derived from Pine seed oil. 
The nanoparticles embedded alkyd resin was found to be active against some bacterial and fungal isolates. The resin was also used to formulate oil-based paints. The paints formulation have a \% PVC range of 3-5\%, hence are classified as automotive clear coats.

\section{References}

[1] AOCS, (1996). Sampling and analysis of commercial fats and triglycerides. Official Methods of Analysis of the AmericanTriglycerides Chemist Society. 801-855.

[2] AyoR.G., Audu O.T., and Omupita J.O. (2007). Physico-chemical characterization and cylotoxicity studies of seeds extract of khaya senehalensis (Desr) A. juss. Africa journal of Biotechnology (7), 894-896.

[3] Kim S.W., S.H, and An Y.J. (2011), Interaction of silver nanoparticles with biological surfaces of caenorhabditis elegans. Ecotoxical Environmental Safety. 77. https://doi.org/10.1016/i.ecoenv.2011.10.023

[4] Kirk R.F., and Othmer D.F., (1966) Encyclopedia of Chemical Technology. 2nd Edition, Interscience Publishers, New York, 1 , 851 - 85

[5] Mathiazhagan A., and Rani Joseph (2011), Nanotechnology- A new prospective in organic coating- Review. International Journal of Chemical Engineering and Applications, (2), 225-228. https://doi.org/10.7763/IJCEA.2011.V2.108.

[6] Maribel G. G., Jean D., and Stephan G., (2009); Synthesis of silver nanoparticles by chemical reduction method and their antibacterial activity, IJCBE, 2-3 M.M Uppal. (2006), Engineering Chemistry 7, Pp 782-783.

[7] Momodu V.M., Omorogbe S.O., Ikhuoria E.U., Obazee E.O., and Aigbodion A.I., (2011). Synthesis and evaluation of performance characteristics of walnut (Tetracarpidium conophorum ) seed oil- modified alkyd resin. Researcher, 3(7), 63-66.

[8] Odetoye,T.E , Ogunniyi, D.S. and Olatunji, G.A. (2012) Improving Jatropha curcas Linneaus seed oil alkyd resins, Progress in Organic Coatings, 73 (4) 374-381. https://doi.org/10.1016/j.porgcoat.2011.11.016.

[9] Ogunniyi D.S (2006), Castor oil: A vital industrial raw material. Bioresources Technology, (97), 1086-1091. https://doi.org/10.1016/i.biortech.2005.03.028.

[10] Oladipo O., Ighodalo C., and Olujinmi M.F., (2013), Formation and characterization of paint based on alkyd resin derivative of Xinenia Americana (wild olive) seed oil. Environment and Natural Resource Research. (3) 53-55. https://doi.org/10.5539/enrr.v3n3p52.

[11] Sondi B., alopek S., (2007), Silver nanoparticles as antimicrobial agent: a case study on E Coli as a model for gram negative bacteria, Journal of Colloid and Interface. (275), 177-182. https://doi.org/10.1016/i.jcis.2004.02.012 